\title{
Hermeneutic Philosophies of Social Science: Introduction
}

Babette Babich

Fordham University, babich@fordham.edu

Follow this and additional works at: https://fordham.bepress.com/phil_babich

Part of the Continental Philosophy Commons, History of Philosophy Commons, Legal Theory Commons, Linguistic Anthropology Commons, Other Social and Behavioral Sciences Commons, Philosophy of Science Commons, Physical and Environmental Geography Commons, $\underline{\text { Political }}$ Theory Commons, Science and Technology Studies Commons, and the Social and Cultural Anthropology Commons

\section{Recommended Citation}

Babich, Babette, "Hermeneutic Philosophies of Social Science: Introduction" (2017). Articles and Chapters in Academic Book Collections. 80.

https://fordham.bepress.com/phil_babich/80 


\section{DE GRUYTER}

Babette Babich (Ed.)

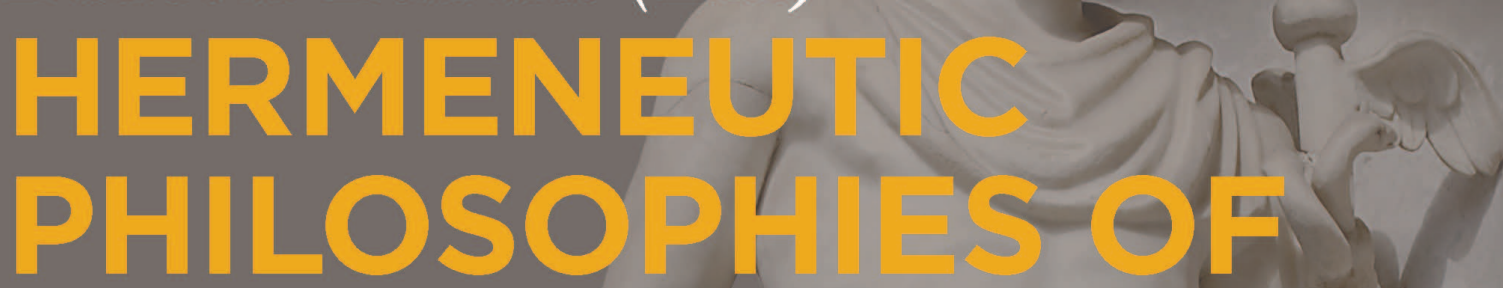

SOCIAL SCI

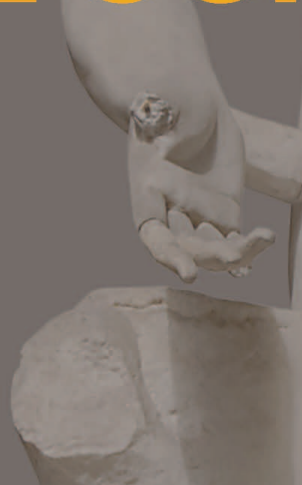




\section{Babette Babich}

\section{Hermeneutic Philosophies of Social Science: Introduction}

Interpretive philosophical reflection, hermeneutics, is inseparable from any philosophy of social science. Indeed, to the extent that the social sciences include the human subject, reflection on reflection is integral and such reflection constitutes, whether one names it as such, or not, part of the hermeneutic turn.

This collection of essays offers a range of hermeneutically minded philosophies of social science foregrounding understanding and including a specific attention to history as well as a methodological reflection on the notion of reflection but also subjective obstruction: 'prejudice' or 'pre-judgments' as Joseph J. Kockelmans speaks of these in his chapter below. This same approach informs what has been called a "humanist" by contrast with a naturalistic approach to the social sciences. ${ }^{1}$ Currently, although fashions change constantly, some contemporary hermeneutic studies include so-called 'thing ontology' (there are other names), and hermeneutic philosophies of social science also embrace social studies of knowledge as well as social studies of natural science as these latter are themselves, as Bruno Latour has long argued, so many social practices.

Yet there is at the same time a tendency to resist the language of hermeneutics in connection with the philosophy of science. This may be further exacerbated today as part of the quantitative turn in today's university-level human and social sciences. In part, this is due to a certain hard-science anxiety on the part of the social scientists themselves who worry, rather as the title of Bent Flyvbjerg's book Making Social Science Matter seems to suggest, ${ }^{2}$ that social inquiry is destined to fall short in those respects that make an inquiry seem to be significantly "scientific."3

Approaches to hermeneutic philosophies of social science that may be considered hermeneutic, quite in spite of this surprisingly durable constellation of anxiety and suspicion, can be found. Examples include James Bohman's New Philosophy of Social Science (1991) and Harvie Ferguson's Phenomenological So-

1 Note that Roger Trigg (1985) reflects on this in his survey.

2 Bent Flyvbjerg's book Making Social Science Matter: Why Social Inquiry Fails and How It Can Succeed Again (Flyvbjerg 2001).

3 This concern is also evident in Bruno Latour's recent An Inquiry into Modes of Existence: An Anthropology of the Moderns (Latour 2013) and Steve Fuller's Philosophy of Science and Its Discontents (Fuller 1989). 
ciology (2006), as well as (analytically styled, despite its title), Yvonne Sherrat's Continental Philosophy of Social Science (2006) and, in spite of an explicit antipathy to hermeneutics in favor of the generic titling of her book, Karin Knorr-Cetina's Epistemic Cultures (1999). ${ }^{4}$ Thus, in addition to general approaches to the philosophy of the social sciences as such, one must also consider the range of "Social Studies" of science, natural and social, including studies of technique and technology, ranging from John Ziman to Bruno Latour and Stephen Woolgar in the early days of their collaboration, together with Barry Barnes and Harry Collins and Trevor Pinch and arguably including even Andrew Pickering along with the analytically minded but sui generis reflections of Steve Fuller. ${ }^{5}$ Other contributions drawing on history have grown into a separate discipline often analytically articulated as part of what is generically known as "history of philosophy." In this tradition, authors comventionally feel constrained to exclude hermeneutics as well as feminist approaches which (when these are not ghettoized in the philosophy of science) can also be lumped in with hermeneutic approaches to social science in the work of Lorraine Code and Hilary Rose ${ }^{6}$ as well as Andrea Nye's work on logic, although Nye's loyalties are explicitly analytic and thus "historicist," alongside other work in feminist epistemology and philosophy of science, both natural and social, although, once again, the great majority of these studies remain 'analytically' rather than 'continentally' minded.

Hans-Georg Gadamer (1900 - 2002) reflected on hermeneutic philosophies of social science in a series of chapters included in his Reason in the Age of Science. ${ }^{7}$ Gadamer's concern emerges in two successive chapters, "Hermeneutics as Practical Philosophy" and "Hermeneutics as a Theoretical and Practical

4 See here Bohman 1991 but also Ferguson 2006 as well as Baumann 2010. Thus although analytic in approach Yvonne Sherrat's Continental Philosophy of Social Science (Sherrat 2006) duly encompasses all "other" approaches to philosophy of science in a specifically "history of philosophy" styled frame and see too, if more in the tradition of history of science studies, Knorr-Cetina 1999. But see, for a discussion including Dilthey, Weber, and Schütz, Harrington 2001. 5 John Ziman was author of many studies in this direction, see in particular his book, The Force of Knowledge: The Scientific Dimension of Society (Ziman 1976) as well as his chapter contribution "No Man is an Island" along with Rom Harré's "Science as the Work of a Community" and Tony O'Connor's "Human Agency and the Social Sciences: From Contextual Phenomenology to Genealogy" all included in the section "Hermeneutics and the Philosophy of Science" in Babich (ed.) 2002, pp. 187-194, 203-218, 219-229.

6 See Code 1991. Code, like Gadamer although her formation is more traditionally analytic, focuses on language and centers on autonomy. See too, if likewise more focused, like Code, on the natural as opposed to the social sciences and more analytically minded than continental, Rose 1994. See too Apel 1979.

7 Gadamer 1983. 
Task." With his accustomed methodological exigence, Gadamer raises the question not of the social sciences as such, nor of hermeneutics in particular but philosophy itself. Thus Gadamer notes the enduring concern of philosophy to keep pace with the sciences, not only as a science among the sciences but also, this would be a double effect, as charged to provide science as such with theory"Wissenschaftstheorie," for Gadamer, refers to the claims of philosophy with respect to the dominion of the sciences in all their diversity, natural and socialbut also corresponding to "the claim of philosophy to be a giving of accounts [Rechenschafts ablegen]."

The task of philosophy in our technoscientific era is to think where, as Heidegger said, "science does not think" and not less to communicate, needful where, as Gadamer says, science "does not really speak a language in the proper sense." $" 10$

Here, we consider Gadamer's observation, inspired by Nietzsche's “demand that one doubt more profoundly and fundamentally than Descartes"), ${ }^{11}$ and further amplified by the "critique of ideology" that

called scientific neutrality into doubt. It questioned not merely the validity of the phenomena of consciousness and of self-consciousness (which was the case with psychoanalysis) but also the purely theoretical validity of scientific objectivity with which the sciences laid claim. ${ }^{12}$

Beginning with Heidegger's reflections on the Greek legacy of rationality inspires "the new notion of interpretation," 13 whereby

The very idea of a definitive interpretation seems to be intrinsically contradictory. Interpretation is always on the way. If, then, the word interpretation points to the finitude of human being and the finitude of human knowing then the experience of interpretation implies something that was no implied by the earlier self-understanding when hermeneutics was coordinated with special fields and applied as a technique for overcoming difficulties in troublesome texts. Then hermeneutics could be understood as a teaching about a technical skill-but no longer. ${ }^{14}$

8 Gadamer 1983, pp. 88-112 and pp. 113-138. See, further, below, the chapters authored by Kockelmans, Madison, Geniusas, and Franeta.

9 Gadamer 1983, p. 2.

10 Gadamer 1983, p. 3.

11 Gadamer 1983, p. 100.

12 Gadamer 1983, p. 100

13 Gadamer 1983, p. 102.

14 Gadamer 1983, p. 105. 
The challenge for Gadamer is to decide between "theory of science" and "philosophy" of science. ${ }^{15}$ Thereby we can begin with his invitation to consider

the traditions within which we stand-and every tradition that we creatively or appropriatively pass on-offer less an objective field for the scientific mastery of a subject matter or for the extension of our domination by knowledge of the unknown than a mediation of ourselves with our real possibilities engulfing us-with what can be and what is capable of "happening" to and becoming of us. ${ }^{16}$

Gadamer argues that "science is no less science where it is aware of the humaniora as its integrative function.” By attending to its hermeneutic dimensionality we enhance rather than diminish science.

Hermeneutic philosophies of the social science as these are represented in the present collection of essays have drawn inspiration from Gadamer's work as well as Paul Ricoeur, Michel de Certeau, and Pierre Bourdieu, in addition to Michel Foucault and Jean Baudrillard. Other contributions foreground Wilhelm Dilthey in addition to Edmund Husserl and Maurice Merleau-Ponty as well as Heidegger's expressly hermeneutic phenomenology in addition to Max Scheler and Alfred Schütz among others. ${ }^{17}$

The term hermeneutics is not without its own attendant baggage, as a methodological approach that has been alternately foregrounded and eclipsed and is currently enjoying renewed attention. Still the word can often be a problem and some reflections are hermeneutic even where the term is not explicitly mentioned or even deliberately kept at a distance. Hence writing on Durkheim and tracing a similar trajectory of influence, Warren Schmaus reflects on interpretation as such, foregrounding method while avoiding the mention of the word "hermeneutics"-thus his book is subtitled "Creating an Intellectual Niche," pointing to the lack of space for the range of approaches that might foreground interpretation as such. Schmaus is hardly the only scholar who favors this tactic: arguably both Clifford Geertz and Paul Rabinow do so as do many others. In turn, this sensitivity highlights the still riven chasm between 'analytic' and 'continental' approaches to philosophy of science, ${ }^{18}$ a separation only deepened by the hierarchical distinction between the natural and the social sciences, Thus, although a number of approaches toward a range of hermeneutic philosophies

15 It is significant that when Gadamer wrote this, the conventional German rendering of 'philosophy of science' was Wissenschaftstheorie. Today the terminology has shifted to a more or less direct translation of philosophy of science: Wissenschaftsphilosophie.

16 Gadamer 1983, p. 167.

17 See, for example, Schmaus 1994, more generally, again, Ferguson 2006.

18 See Babich 2010, 2012, and 2015a. 
of the social sciences exist, ${ }^{19}$ the authors, even when they are continental themselves, can be inclined to downplay the specific role of hermeneutics in the approaches they argue.

Today, most philosophers of science are trained in analytic philosophy, not "continental philosophy"-largely because universities are almost uniformly analytic. Thus even schools that had been traditionally "continental" have since hired analytically trained scholars even for continental appointments (the academic political element being the missing shade of blue in Thomas Kuhn's Structure of Scientific Revolutions). Thus the painful wake of the so-called science wars foregrounds "genealogy" by which is meant more Foucault than Nietzsche. As a kind of micro-illustration of the same point, although Nietzsche himself wrote sustained hermeneutic reflections on history, analytic studies of Nietzsche's philosophy of history, including Emden and Jensen as well as, on the political side, Drochon, etc., rather uniformly tend to elide, often in good conscience and often, in good analytic fashion, describing their own approaches as 'continental,' exclude hermeneutics along with critical theory. Here it should also be noted that formations are mixed in the case of the contributions here included, not only advancing hermeneutic philosophies of social science, but drawing on other approaches including pragmatism, and "process" philosophy and other traditions.

The strength of this book collection thus reflects the richness of the hermeneutic tradition just as it draws on every area of philosophical reflection, illustrating the past diversity of hermeneutic approaches as well as the future possibilities for hermeneutic and phenomenological philosophies of social science. The interpretation of texts and practices, including hermeneutic phenomenology's special attention to the life-world is seen in the contributions to follow as articulating questions of the sociology of knowledge as well as specifically applied ethics and the law, cultural theory, as well as reflections on education and exploration of themes drawn from history of philosophy, from Plato to Descartes.

19 See, on the continental side, the contributions of Kockelmans and Heelan in particular, but see also, albeit more analytically minded (this has regrettably not led to a reception among his analytic peers), Dmitri Ginev's many studies, perhaps especially his contribution "Micro- and Macro-Hermeneutics of Science" to a volume Ginev edited with the late Robert S. Cohen (in honor of Azarya Polikarov), Issues and Images in the Philosophy of Science (Ginev and Cohen 1997), pp. 87-94 in addition to Ginev's own "Rhetoric and Double Hermeneutics in the Human Sciences” (Ginev 1998). 


\section{Kinds of Hermeneutic Philosophies of the Social Science}

The very notion of a hermeneutic philosophy of social science highlights reflexive plurality. Typical hermeneutic approaches to the social sciences may, as already noted, be traced in the writings of Dilthey, ${ }^{20}$ Schütz, ${ }^{21}$ Scheler ${ }^{22}$ but not less Weber ${ }^{23}$ as well as Gadamer, ${ }^{24}$ Ricoeur as well as, from the perspective of Critical Theory, Theodor Adorno. To this list can be added, in differing interpretive fashions, Bourdieu, Alasdair MacIntyre, Niklas Luhmann, Jacques Ellul, Baudrillard, as well as de Certeau (who himself reads between Foucault and Baudrillard) and Paul Virilio, etc. We have already seen that to this must be added the tendency of theorists like Geertz and Charles Taylor to adopt some of tactics and foci of hermeneutics while excluding engagement with the tradition (all those other names of all those many philosophers and fellow travelers) and routinely excluding the term hermeneutics from their discussions. ${ }^{25}$ Such terminological suppression is part of the politics and thus the professional tactics of institutional or university philosophy of science, be it of a social or natural kind.

Already one needs a definition of a specifically hermeneutic philosophy of social science. At the same time there are debates about whether one ought to

20 See here, very directly, Wilhelm Dilthey's own Introduction to the Human Sciences: An Attempt to Lay a Foundation for the Study of Society and History (Dilthey 1988). In addition to Buloff 1980 as well as Bakker 1999, including a discussion of the tensions between Heidegger's and Dilthey's hermeneutic approaches. And see too in the present volume, Nelson and Scharff below. Useful here too is Bambach 1995. And see, if more recondite than a first introduction can reasonably expect to be, Thouard 2005.

21 See, in general, the contributions to Michael Staudigl and George Berguno's collection, Schutzian Phenomenology and Hermeneutic Traditions (Staudigl and Berguno 2014), particularly, in that same volume, Martin Endress' "Interpretive Sociologies and Traditions of Hermeneutics" (Endress 2014).

22 Scheler 1980.

23 See for a useful discussion focused in particular on Weber's appropriation of Aristotle, McCarthy 2009, pp. $100 \mathrm{ff}$.

24 In addition to Joseph Kockelmans's useful discussion below, together with Hans-Georg Gadamer's own contribution to an issue of the New School journal dedicated to his work, "The Problem of Historical Consciousness" (Gadamer 1975), see, very classically, and note that both of the examples are counterpoised with other names, Georgia Warnke, "Hermeneneutics and the Social Sciences: A Gadamerian Critique of Rorty" (Warnke 1985) as well as, more recently, Edward W. Gimbel, "Interpretation and Objectivity: A Gadamerian Reevaluation of Max Weber’s Social Science” (Gimbel 2016). But see too, Rorty 2003.

25 There are exceptions as I note some of them here and throughout this introduction, see for example Fred Dallmayr's "Hermeneutics and Cross-Cultual Encounters: Integral Pluralism in Action" in Dallmayr (2010), pp. 103-122. And see too Mohr/Rawlings 2013, Gibbons 2006, and Heller 1989. 
speak of a hermeneutic or else of a phenomenological approach (thus the utility of combination approaches such as the Heideggerian hermeneutico-phenomenological approach) to the social sciences. To these debates, not that adding things to the mix is especially helpful apart from indicating the breadth of the problem, one may add the important dispute concerning Emile Durkheim (there is a hermeneutic dispute about this given the differing attributions of positivism between Francophone and Anglophone traditions along the periphery of which one place the German and the Dutch and Flemish traditions). ${ }^{26}$ In addition to the disparate foci between Francophone and Anglophone taxonomies of the hermeneutics of social science, there is also a distinctive German tradition. One may note, for example the range of contributions to the book collection on specifically hermeneutic sociology of knowledge ${ }^{27}$ in addition to methodological explorations. ${ }^{28}$ And in the literature of the 1980s, in addition to Simon Glynn's $1986 \mathrm{Eu}$ ropean Philosophy and the Social Sciences ${ }^{29}$ we may note Dieter Misgeld's 1989 and overtly preliminary discussion of the articulation between phenomenology and hermeneutics in sociology. ${ }^{30}$ In addition, read from a more general as well as more mainstream perspective in the philosophy of science, writing in 1979, on the cusp of the1980s, Dagfinn Føllesdal makes the (now standard analytic) case that the hermeneutics of science may be regarded as a special case of philosophical (analytic) approaches to scientific methodology. ${ }^{31}$ In just this way, to be sure, analytic philosophy has typically tended to discredit the value of hermeneutic philosophical approaches claiming that it was something they were already doing. Such assertions have however also been combined with claims of

26 Thus Jeffrey C. Alexander can claim at the start of his own discussion of this dispute in his book Durkheimian Sociology: Cultural Studies (Alexander 1990) that Steven Lukes may well take responsibility for excluding Durkheim from the hermeneutic tradition on the grounds that "Durkheim took a positivist rather than a hermeneutic position." Alexander 1990, p. 16. Cf., here, Lukes 1972. Of course this is a complex point and see further Bloor 1982 as well as Johan Heilbron 2004. See Alexander's more recent article, co-authored with Philip Smith, "The Strong Program in Cultural Theory: Elements of a Structural Hermeneutics" (Alexander and Smith 2001). The thematic remains relevant and Stjepan Mestrovic reads Durkheim as a hermeneuticist to assist a finer point with respect to sociological method contra his topical assessment of Anthony Giddens: The Last Modernist (Mestrovic 2005).

27 Hitzler, Reichertz and Schröer 1999.

28 Moses and Knutsen 2012.

29 Glynn 1986.

30 Cf. Misgeld 1989.

31 Føllesdal 1979. 
incomprehensibility (vague, badly written, what is the argument?) along with declarations of a lack of interest (dated, tiresome, and so on). ${ }^{32}$

Not at lot would seem to have changed in contemporary Anglophone philosophy, which may still be named, for better or for worse, "analytic"-although the designation is increasingly refused to the extent that analytic philosophy having long refused to recognize the value of continental philosophy regards its own approach to traditionally continental themes and thinkers as the only valid or viable approach. We are beyond the analytic-continental divide, so we are told (this claim arguably dates back to the beginning of the division). And the assertion is as good as true-not because the divide has been abolished or differences overcome or bridges built and borders dissolved but simply because analytic philosophy (hence the near ubiquity of its terminological conventions, like "naturalism"), is by and large the philosophy taught at university. Thus most the overwhelming majority of professional philosophers today enjoy an analytic background, This is because for the last two or three decades, university appointments in the US, the UK, France, and Germany and Italy and so on have gone to analytically informed or formed academics who nonetheless vociferously resist the designation as analytic and sometimes, the most notable case being Brian Leiter, regard themselves as 'continental.'33

Quite apart from such terminological tensions, the hermeneutic approach remains unsettling as the social sciences continue to be embroiled in a certain crisis of method arguably attributable to the dominant model of the natural sciences. This is witnessed in recent years by a turn toward the quantitative (and thus the quantifiable) compounded by the new, so-called "datalogical" or digital turn, which although it promises new insights, continues the modeling of the social sciences on the paradigm of the hard sciences. Paradoxically perhaps, current discussions of "big data," with its strange properties of emergence and relation, can only require (which is not to say that today's theorists embrace) a hermeneutic turn. ${ }^{34}$

32 Thus some three decades ago now, Mark Okrent offered such a strategization in his essay on hermeneutics and social science. Okrent 1984: 23-49.

33 I discuss some of these problems in a dialogue with the philosopher and gaming designer and theorist, Chris Bateman, see Babich and Bateman 2016. The dialogue is one of series of dialogues, published at the end of 2016, continuation ongoing through 2017.

34 This has not yet been completely developed. Though not expressly hermeneutic, see, Lynch 2016 as well as the contributions to Pietsch et al., 2017 and Stingl 2015. I discuss this and related elements in Babich 2018. 
Where the natural sciences appear to have a clear hierarchy-physics at the top, followed (with some contentiousness) by chemistry, ${ }^{35}$ biology and so on with some debate as to where to find or to set sciences like cosmology, clearly with astronomy, at least on some accounts at the same level as physics itself, or oceanography and the earth sciences, as well as cross-over sciences such as geography and, complicated by today's political debates, meteorology and climate science, in this volume there will be some discussion of the latter sciences in connection with coastal science (and engineering) politics-there is, by contrast, no clearly privileged top "social science," although as the late Gary Madison points out, many have sought to give this title to economics, precisely owing to its precision. ${ }^{36}$ Nevertheless, among what the Germans call the sciences of spirit or intellect or mind, the Geisteswissenschaften, may be counted economics, history, political science, sociology, anthropology, psychology, sociolinguistics but not less educational theory and reflection ${ }^{37}$ as primary social sciences, to which sciences some cultural traditions include theology and philosophy as well as among the other historical and human and social sciences.

\section{Plan of the Text}

\section{VI.1}

The first section, entitled Science and Method: Towards Hermeneutic Phenomenology of Social Science, takes its inspiration and point of departure from an explicit reflection on this very topic in a classic study, key to this collection as whole, in the essay by the Dutch philosopher of science Joseph J. Kockelmans (1923-2008): “Toward an Interpretative or Hermeneutic Social Science." In his essay, Kockelmans raises the question of the role and use of hermeneutic philosophy in the philosophy of the social sciences. Taking as point of departure Heidegger's hermeneutic phenomenology, Kockelmans reads Gadamer's reflections on history as well as his Truth and Method. In each case, for Kockelmans, what is methodologically essential is to articulate what can be elicited for the purposes of a philosophy of the social sciences, including an overview of objections that

35 See for example the contributions to Baird, Scerri and McIntyre 2006 and my own review of this disciplinary claim with additional literature in Babich 2010.

36 See Madison 1990.

37 See Babich 2012. Bruno Latour's own contributions to this review are discussed among others in Babich 2015a and briefly in my own essay in this volume. Cf. Felder 2013 and Pierozak 2016 in addition to Feussi 2016. 
may be offered. Thus Kockelmans explores the sense in which Heidegger's and especially Gadamer's ideas about philosophy can be valuable for a philosophy of the social sciences.

This second chapter was composed in direct correspondence with Kockelmans by his friend and intellectual co-traveler, the Belgian-Irish physicist and philosopher of science, Patrick Aidan Heelan (1926-2015). Heelan's own expertise was in measurement and waves, in developed in his work with Erwin Schrödinger which lead to the quantum philosophy, as Heelan would speak of it, of Werner Heisenberg. ${ }^{38}$ In "Quantum Mechanics and the Social Sciences," Heelan develops the argument that quantum mechanics may be interpreted, in the spirit of Niels Bohr and Werner Heisenberg, as being about physical objects in so far as these objects themselves are revealed by and within the local, social, and historical process of measurement. Heelan shows that a reading of the hermeneutical aspect of quantum mechanical measurement reveals close analogues with hermeneutical social/historical sciences. In conclusion, Heelan argues that the hermeneutical analysis of science requires the move from the epistemological attitude to an ontological one.

The next chapter follows, as it were, this very move to social theory, not qua traditionally received and not only in terms of conventional social studies of science but critically reflected. Thus the intersection between hermeneutics and critical theory is explicitly thematized in the chapter contributed by Hans-Herbert Koegler, a German philosopher who has taught for many years in Florida: "A Critical Hermeneutics of Agency: Cultural Studies as Critical Social Theory." Observing that research practices commonly labeled as "cultural studies" are the productive continuation of the epistemic interests pursued by the early Frankfurt School, Koegler argues that cultural studies represent the reflexive and creative diversity emblematic of everyday practices, whereby, following Adorno, it is common to underscore an element of subversion of resistance even in standardized "entertainment-products." Koegler asks how social practices of power influence, by means of producing meaning, the self-understanding of subjects, and how those subjects themselves are in turn capable of influencing and changing their respective cultural and social practices. Koegler's further question, given all the contradictions of individual self-understanding, asks how power might be "anchored" in subjective interiority?

In the next chapter, Eric S. Nelson, "Overcoming Naturalism from Within: Dilthey, Nature, and the Human Sciences” focuses on Dilthey's understanding

38 For a retrospective and overview of this, see Heelan's posthumously published book, The Observable, Heelan 2016. 
of nature and spirit in the 1890s, in terms of the debate between naturalism and anti-naturalism. For Nelson, Dilthey outlines the limits of natural scientific methods in the face of the felt reflexivity of the subject, the singular nexus of individual life, together with the inability of humans to know and comprehend life as a comprehensive universally valid systematic whole. Thus Dilthey immanently demonstrates naturalism's possibilities and limits in relation to the psychological, historical, and ethical life of individuals without appealing to essentialist, religious, or metaphysical conceptions of a substantial self. Because lived-experiences are complex relational wholes involving purposiveness, they cannot be coherently and adequately reduced to or reconstructed as discrete "natural" elements abstracted from the complex nexus of life.

In the final contribution to this first section, Steve Fuller, the US born philosopher of science and sociologist, based at Warwick, offers an intentionally explosive reflection: "Hermeneutics from the Inside-Out and the Outside-In-And How Postmodernism Blew It All Wide Open.” Fuller's language of an 'insideout' vs. 'outside-in' approach to hermeneutics, distinguishes the human sciences from the natural sciences. As Fuller reminds us, the social sciences have been the historic testing ground for both approaches. But today, on Fuller's view, the postmodern condition has exploded this traditional dialectic, challenging the shared assumption that the 'human' is a member of Homo sapiens, a classificatory assumption from the second half of the 18th century to the second half of the 20th century. Fuller concludes his chapter by raising the question of the viability of hermeneutics in a world where the 'human' is thus ontologically indeterminate.

\section{VI.2}

The next section, Reflexive and Relational Hermeneutics, begins with a contribution by the philosopher and historian, Steven Shapin. In his chapter, "The Sciences of Subjectivity," Shapin talks about one of the subjective sciences via what can seem to be the most subjective of all the senses: gustation, that is, taste and tasting. Shapin sets up his reading by referring to what he calls a "long-standing fascination with deflating certain stories about objectivity." Foremost in this deflationary enterprise is subjectivity as such which presents difficulties for objective demonstration by contrast with standard sorts of knowledge. To focus on subjectivity, Shapin traces potentially constructive links between contemporary science studies and resources in $18^{\text {th }}$-century philosophical aesthetics. In particular, looking at wine, Shapin's focus concerns available engagements with the mode of subjectivity known as taste, and, especially, gustation 
and olfaction, to suggest ways in which we might study the achievement of intersubjectivity in these domains.

In his contribution, Dimitri Ginev calls upon the notion of double hermeneutic to address both reflexivity and the elusive notion of the ontological difference. Ginev's chapter, "Studies of Empirical Ontology and Ontological Difference," criticizes the tendency to radical empiricization of empirical ontology while supporting the anti-foundational ontological turn in science and technology studies. On the cognitivist argument, the empirical immediacy is inevitably shaped and mediated by non-empirical assumptions. However, according to the hermeneutic argument, any empirically immediate state of affairs is the upshot of actualizing possibilities projected by interrelated practices upon horizons of practical existence. Thus, the actually given qua empirical immediacy is ineluctably "produced" within the potentiality for practical being. Following this, Ginev suggests a non-empirical extension of empirical ontology, specifically illustrated by way of the integration of radical reflexivity in ethnographic descriptions of multiple realities before reflecting on the introduction of double hermeneutics in the studies of empirical ontology.

The third chapter in this section, Babette Babich, "Hermeneutics and Its Discontents in Philosophy of Science: On Bruno Latour, the "Science Wars", Mockery, and Immortal Models “ reviews the fortunes of Alan Sokal's 1996 hoax, including the politics of mockery. A hermeneutic reflection on the history and philosophy of science highlights the relevance of the hegemony of analytic style in philosophy, discussed in terms of both the Forman thesis in the History of Science as well as the fate of Latour's lab-ethnography cum field ethnography, along with socio-linguistics and the political force of rhetoric as a means of excluding other voices, especially within professional philosophy and philosophy of science in particular. The paper concludes with a discussion of the politics of scientific publishing in the context of shoreline modelling, "immortal" or zombie models as these persist in the face of (or better said: absence of) empirical feedback.

In the first of the last two dialogically-related concluding contributions in this section, the late Canadian philosopher, Gary Madison (1940-2016) writes "On the Importance of Getting Things Straight” to emphasize the order of knowing, including clarification, requests for further information, etc. Thus Madison argues that it is curious that phenomenological (or philosophical) hermeneutics, a systematic theory of human understanding in all its various forms, continues to be so widely misunderstood as it has been. Nevertheless, as phenomenology has shown, human understanding invariably tends to misunderstand itself. Madison finds it striking that the two chief ways in which hermeneutics is commonly misunderstood are themselves diametrically opposed to one another. With this 
advance response, the reader is better prepared to approach the final chapter of this section, the Lithuanian philosopher, Saulius Geniusas' reflections on "HansGeorg Gadamer's Concept of the Horizon and Its Ethico-Political Critique.” Geniusas focuses on the relevance of Gadamer's hermeneutics in the context of today's socio-political concerns. In question are ethically and politically motivated critiques of Gadamer's hermeneutics, especially those of Richard Kearney, who suggests that Gadamer fails to offer a satisfactory account of the relation between ipseity and alterity. Geniusas argues, per contra, that Gadamer's hermeneutics does not overlook the otherness of the Other. Here, Geniusas concludes that the fusion of the horizons abolishes neither the self, nor the Other, but raises both to a higher universality. The oneness of the horizon(s) thereby proves to be the dialogue that we ourselves are.

\section{VI.3}

The third section of this book focuses on Practice and Application: Hermeneutics, Social Theory, Pragmatics. The first contribution is offered by the hermeneutic legal scholar, Duška Franeta, offering a reading of “Gadamer's Hermeneutics as Practical Philosophy” in an explicitly applied context. Franeta explores the connection of philosophical hermeneutics in Aristotle's practical philosophy, noting that the fundamental notions of prejudice, hermeneutical circle, tradition, situation, effective-historical consciousness, fusion of horizons and application underwrites Gadamer's central thesis that our understanding is never mere subject-oriented behavior but always also historically limited. Thus Gadamer intends to show that we can never fully escape from all of our prejudices but not that we cannot encounter them critically. Indeed, the fact that we cannot erase our own horizon when approaching someone else may invite us to seek instead to find a common ground with them inasmuch as the process of understanding always has a dialogical character. Franeta concludes by outlining the revival of self-understanding of humanities, universal competence of scientific experts and domain and objectives of contemporary education.

In the following contribution, the German theorist of the sociology of knowledge, Bernt Schnettler (Bayreuth), along with his co-authors, Hubert Knoblauch (TU Berlin) \& Jürgen Raab (Koblenz-Landau), offers a review of what has been, in a German context, known as “The 'New' Sociology of Knowledge.” This novel approach was developed in a characteristic context as philosophical reflection on the conditions of human thinking and reasoning, subsequently evolving into a specific sociological perspective on the social conditions of knowledge production and dissemination. The social character of thinking has long been observed 
from Bacon to Marx, and numerous theorists, as Schnettler/Knoblauch/Raab point out, have emphasized the distorting effects social influences have upon individual thinking. Ultimately, the authors argue, thinking and knowledge production depend fundamentally on their social genesis.

In his contribution to this collection, the French sociolinguist, Didier de Robillard looks at de Certeau in connection with both history and sociolinguistics in his chapter, "Taking Plurality Seriously with Michel de Certeau: From History to 'Reception Sociolinguistics'," specially translated for this volume by Tracy Burr Strong, who was himself de Certeau's colleague in San Diego for several years. As one of the most important theorists of practical or engaged hermeneutics in everyday social engagement, de Robillard shows that the French sociological and praxical philosopher, Michel de Certeau. But de Certeau was also concerned with sociology and with language in addition to history. De Robillard details the conjunction of hermeneutics and sociolinguisitics via a reading not only of de Certeau but also the French research tradition of sociolinguisitics as a hermeneutic practice of Certeaulian everyday life.

The penultimate chapter of the second section is offered by the pragmatic philosopher and student of (and collaborator with) Richard Rorty, Barry Allen, "Pragmatism and Hermeneutics." Here, Allen offers a kind of hermeneutics of pragmatism itself, bringing his own signature style together with the resources of hermeneutics to explicate the intersection of "Practice" as a kind of applied pragmatism. Still, if perhaps surprisingly, the word pragmatism scarcely appears in Rorty's Philosophy and the Mirror of Nature. Rorty's terminology, on Allen's report, is epistemological behaviorism which was a term quickly replaced by anti-representationalism, and which, together with thoughts on literature and politics, formed Rorty's version of pragmatism. Yet Allen points out that Philosophy and the Mirror of Nature was written for "professional consumption." Thus Allen underscores that Rorty would have had no need to reach out to analytic epistemologists, inasmuch as he himself was already one of them. For Allen, the writing of Philosophy and the Mirror of Nature would take Rorty beyond that tradition, indeed and as the title of one of Rorty's chapters suggests, "From Epistemology to Hermeneutics."

Paul Fairfield's contribution rounds out this section and in his comprehensive set of reflections, "Make It Scientific: Theories of Education from Dewey to Gadamer," Fairfield notes that faculties of education have always been keen to associate their discipline with the social sciences. Thus university schools of education assert a claim to scientificity in ways largely reminiscent of the early days of sociology, psychology, political science, and other established disciplines of the social sciences. Research produced by "educationalists" is expected to conform to all the protocols of empirical and quantitative methodology, raising 
the hope in many minds that the essential business of education might finally transcend the contested realm of art and philosophy and be placed on the secure path of a science. As educational discourse assumed an increasingly empirical and psychological guise through the course of the $20^{\text {th }}$ century, the imperative to legitimate teaching methods as "scientific" is ubiquitous both on the side of conservatives and progressives as faculties of education seek to establish their credentials within academe.

\section{VI.4}

The final section of this collection, Truth and Life: Philosophy and History, Psychology and Method, is broader in its scope and consequently in detail. To this extent, this collection endeavors to go some way to inciting continued reflection on just this broad range of possibilities. In his lead contribution, the English philosopher by origin, though a securely native Floridian by now, perhaps owing to his brilliant dedication as a swimmer and part-time (if non-Nietzschean) Dionysian, Simon Glynn's “The Hermeneutical Human and Social Sciences” offers a review of the hermeneutic social and human sciences themselves including a subject focused reflection and illustration. Glynn reflects on the original function of hermeneutic interpretation for textual exegesis of scripture as well as classical philological and legal texts. Glynn takes the broadening application of literary approaches to cultural artifacts including theatrical performances. In this context, Glynn argues that hermeneutic interpretation offers a valuable tool for understanding of human behavior including social, cultural, historical, political and economic etc., action, interactions and relations and not less related institutions.

In his contribution, the German philosopher, Harald Seubert, who is currently professor in Basel, offers us a philosophy, systematically articulated, of life. In "Life, Metaphysics, History: Reflections on the Contemporary Relevance of Dilthey's Philosophy of Life," Seubert reviews Dilthey's later life dream interpretation of nothing less quintessentially academic than Raphael's School of Athens. Beginning with Dilthey's dream division of the philosophical schools into the irreconcilable camps of positivism, freedom idealism and objective idealism, each internally coherent and incommunicative and thus other-excluding, Seubert argues that Dilthey's signal insight into the irreversible deficiencies of freedom begins in historical awareness. After Fichte and Hegel, and via Husserl and Heidegger, Yorck and Ranke, Seubert draws on both Stephan Otto and Manfred Riedel to illuminate Dilthey's philosophy of life as a first (or foundational) hermeneutic science. 
The concluding three chapters exemplify the breadth of this collection, focusing on the history of philosophy, considered through the lens of Alfred North Whitehead's enduring aperçu, elevating and relegating us at once to mere footnotes to Plato in addition to a discussion of Heidegger and Dilthey on history to conclude with an elegantly hermeneutic reading of Descartes. In the antepenultimate chapter, "Four Fundamental Aspects of the Reversal of Platonism," Lawlor argues that any attempt to reverse Platonism is itself derivative from Plato's dialogues and the interiority of thought (Theatetus), its multiplicity (Parmenides) and spontaneity (Republic, Book VII) as well as the imagination of the political as the life of the mind: the soul (Book II). Lawlor argues that the reversal of Platonism means conceiving forms or essences as events and, on Derrida's suggestion, aims to reduce violence to a minimum. Where Platonism wills the end, hence on Derrida's terms, directed to the violence of the worst, Lawlor argues for a "hyperbolic Gelassenheit" as the only genuine reversal of Platonism.

The next contribution by Robert C. Scharff is addressed to the philosophy of history: "Heidegger: Hermeneutics as 'Preparation' for Thinking." For Sharff, Dilthey's understanding of historical life "in its own terms" inspired Heidegger's early conception of phenomenology as a philosophy requiring "hermeneutical" preparation. In this context, Scharff maintains that it is likewise through Dilthey that Heidegger would contend that in Nietzsche's second Untimely Mediation, Nietzsche "understood more about [being historical] than he made known."

The final chapter of this book contributed by the American philosopher, David Blair Allison (1944-2016) leaves us with a hermeneutic reading as an art, in lento, focused on René Descartes, the philosopher of the clear and the distinct, the philosopher whose turn to subjective certainty inaugurates modernity and might to this same extent seem to require the resources of hermeneutics least of all. But Allison's review of “Hermeneutic Reflections on Descartes' Introduction to His Meditations on First Philosophy" includes a reading of Descartes' own account of his project. Allison's beautifully written exploration adumbrates the key method of any hermeneutic approach to a philosophical text in a philosophically interpretive parallel to Ranke's ideal of history as it itself actually was [eigentlich gewesen], what Descartes himself "actually" says. Inevitably such a reading offers profound and provocative insights into Descartes' epistemological project beyond traditional accounts.

\section{References}

Alexander, Jeffrey C. (1990) Durkheimian Sociology: Cultural Studies. Cambridge: Cambridge University Press. 
Alexander, Jeffrey C. and Smith, Philip (2001) "The Strong Program in Cultural Theory: Elements of a Structural Hermeneutics." In: Jonathan H. Turner (ed.), Handbook of Sociological Theory. Frankfurt a.M.: Springer, pp. 135-150.

Apel, Karl-Otto (1979) "The Common Presuppositions of Hermeneutics and Ethics: Types of Rationality beyond Science and Technology." Research in Phenomenology 9(1): 35-53.

Babich, Babette (2002) "Sokal's Hermeneutic Hoax: Physics and the New Inquisition." In: Hermeneutic Philosophy of Science, Van Gogh's Eyes, and God. Dordrecht: Kluwer, pp. 67-78.

Babich, Babette (2003) "On the Analytic-Continental Divide in Philosophy: Nietzsche's Lying Truth, Heidegger's Speaking Language, and Philosophy." In: Carlos Prado (ed.), A House Divided: Comparing Analytic and Continental Philosophy. Amherst, NY: Humanity Books, pp. $63-103$.

Babich, Babette (2010) "Towards a Critical Philosophy of Science: Continental Beginnings and Bugbears, Whigs and Waterbears." International Journal of the Philosophy of Science 24 (4): $343-391$.

Babich, Babette (2012) La fin de la pensée? Philosophie analytique contre philosophie continentale. Paris: L'Harmattan.

Babich, Babette (2013) "O, Superman! or Being Towards Transhumanism: Martin Heidegger, Günther Anders, and Media Aesthetics." Divinatio (January 2013): 83-99.

Babich, Babette (2015a) “Calling Science Pseudoscience: Fleck's Archaeologies of Fact and Latour's 'Biography of an Investigation' in AIDS Denialism and Homeopathy." International Studies in the Philosophy of Science 29(1): 1-39.

Babich, Babette (2015b) "Sakrale Huren und das Fetisch-Fragment. Batailles Kriegstagebücher Sur Nietzsche.” In: Artur R. Boelderl (ed.), Bataille. Vienna: Turia \& Kant, pp. 275-298.

Babich, Babette and Chris Bateman (2016) "The Last of the Continental Philosophers." Online. 29 November 2016. http://onlyagame.typepad.com/only_a_game/2016/11/ba bich-and-bateman-1.html.

Babich, Babette (2018) "Hermeneutic Perspectives on the Politics of Technology: GPS Hacking Hackers, Virilio's Teratology of Pain, and Airport Security” In Nolen Gertz and Peter-Paul Verbeek, eds., Security and the Political Turn in Philosophies of Technology. Forthcoming.

Babich, Babette (ed.) (2002) Hermeneutic Philosophy of Science, Van Gogh's Eyes, and God. Dordrecht: Kluwer.

Baird, Davis, Scerri, Eric and McIntyre, Lee (eds.) (2006) Philosophy of Chemistry: Synthesis of a New Discipline. Dordrecht: Springer.

Bakker, J.I. (1999) "Wilhelm Dilthey: Classical Sociological Theorists," Journal of Alternative Perspectives 22: 43-82.

Bambach, Charles (1995) Heidegger, Dilthey, and the Crisis of Historicism. Ithaca: Cornell University Press.

Bataille, George (1985) “The Notion of Expenditure.” In: George Bataille, Visions of Excess, tr. Allan Stoeckl. Minneapolis: University of Minnesota Press, pp. 116-129.

Bataille, George (1991) The Accursed Share, tr. Robert Hurley. Cambridge: MIT Press.

Baumann, Zygmunt (2010) Hermeneutics and Social Science: Approaches to Understanding. London: Routledge.

Birault, Henri (1966) "De la beatitude chez Nietzsche." Nietzsche: Cahiers de Royaumont 6: $13-28$ 
Birault, Henri (1977) "Beatitude in Nietzsche.” In: David B. Allison (ed.), The New Nietzsche. New York: Dell, pp. 219-231.

Bloor, David (1982) "Durkheim and Mauss Revisited: Classification and the Sociology of Knowledge." Studies in History and Philosophy of Science Part A, Volume 13, Number 4 (December): 267-297

Bohman, James (1991) New Philosophy of Social Science. Cambridge: MIT Press.

Braver, Lee (2015) "Hermeneutics and Language Philosophy." In: Jeff Malpas and Hans Helmuth Gander (eds.), The Routledge Companion to Hermeneutics. London: Routledge, pp. 634-643.

Brown, Mark B. (2009) "Bruno Latour and the Symmetries of Science and Politics." In: Mark B. Brown, Science in Democracy: Expertise, Institutions, and Representation. Cambridge: MIT Press.

Buloff, Ilse (1980) Wilhelm Dilthey: A Hermeneutic Approach to the Study of History and Culture. The Hague: Nijhoff.

Code, Lorraine (1991) What Can She Know? Feminist Theory and the Construction of Knowledge. Ithaca: Cornell University Press.

Dahlstrom, Daniel O. (1994) Das Logische Vorurteil: Untersuchungen zur Wahrheitstheorie des frühen Heidegger. Vienna: Passagen.

Dallmayr, Fred R. (1989) "Life-World: Variations on a Theme.” In: Stephen K. White (ed.), Life-World and Politics: Between Modernity and Postmodernity: Essays in Honor of Fred Dallmayr. Notre Dame: University of Notre Dame Press, pp. 25-65.

Dallmayr, Fred R. (2010) Integral Pluralism: Beyond Culture Wars (Lexington: University of of Kentucky Press.

Dilthey, Wilhelm (1988) Introduction to the Human Sciences: An Attempt to Lay a Foundation for the Study of Society and History, tr. Ramon Betanzos. Detroit: Wayne State University Press.

Dilthey, Wilhelm (2002) The Formation of the Historical World in the Human Sciences. Collected Works, Volume III. Princeton: Princeton University Press.

Dolling, Lisa (2002) "Dialogue as Praxis: Philosophical Hermeneutics, Historical Epistemology, and Truth." In: Carol C. Gould (ed.), Constructivism and Practice: Toward a Historical Epistemology. Lanham, MD: Rowman \& Littlefield, pp. 33-46.

Ellul, Jacques (1967) The Technological Society, tr. John Wilkinson. New York: Vintage.

Endress, Martin (2014) "Interpretive Sociologies and Traditions of Hermeneutics." In: Michael Staudigl and George Berguno (eds.), Schutzian Phenomenology and Hermeneutic Traditions. Frankfurt a.M.: Springer, pp. 33-54.

Felder, Ekkehard (ed.) (2013) Faktizitätsherstellung in Diskursen: Die Macht des Deklarativen. Berlin/Boston: De Gruyter.

Ferguson, Harvie (2006) Phenomenological Sociology: Experience \& Insight in Modern Society. London: Sage.

Feussi, Valentin (2016) “'Croyance originaire' et élaboration de sens. Quelles conséquences pour la sociolinguistique?” Glottopol 28: 226-241. Online: http://www.univ-rouen.fr/dya lang/glottopol.

Flyvbjerg, Bent (2001) Making Social Science Matter: Why Social Inquiry Fails and How It Can Succeed Again. Cambridge: Cambridge University Press.

Føllesdal, Dagfinn (1979) "Hermeneutics and the Hypothetico-Deductive Method." Dialectica 33(3-4): 319-336. 
Fuller, Steve (1988) Social Epistemology. Bloomington: Indiana University Press.

Fuller, Steve (1989) Philosophy of Science and Its Discontents. Boulder: Westview Press.

Gadamer, Hans-Georg (1975) "The Problem of Historical Consciousness." Graduate Faculty Philosophy Journal 5(1): 8-52.

Gadamer, Hans-Georg (1977) Philosophical Hermeneutics. Berkeley: University of California Press.

Gadamer, Hans-Georg (1983) Reason in the Age of Science, tr. Frederick G. Lawrence. Cambridge: MIT Press.

Geertz, Clifford (1971) The Interpretation of Cultures. Selected Essays. New York: Basic Books.

Geertz, Clifford (1983) Knowledge: Further Essays in Interpretive Anthropology. New York: Basic Books.

Gibbons, Michael T. (2006) "Hermeneutics, Political Inquiry, and Practical Reason: An Evolving Challenge to Political Science." American Political Science Review 100(4): 563-571.

Gimbel, Edward W. (2016) "Interpretation and Objectivity: A Gadamerian Reevaluation of Max Weber's Social Science." Political Research Quarterly 69(1): 72-82.

Ginev, Dimitri (1997) A Passage to the Hermeneutic Philosophy of Science. Amsterdam: Rodopi.

Ginev, Dmitri (1998) "Rhetoric and Double Hermeneutics in the Human Sciences." Human Studies 21: 259-271.

Ginev, Dmitri and Cohen, Robert S. (1997) Issues and Images in the Philosophy of Science. Dordrecht: Kluwer.

Glynn, Simon (1986) European Philosophy and the Social Sciences. Aldershot: Gower.

Habermas, Jürgen (1988) On the Logic of the Social Sciences, tr. Shierry Weber Nicholsen and Jerry A. Stark. Cambridge: MIT Press.

Harrington, Austin (2001) Hermeneutic Dialogue and Social Science: A Critique of Gadamer and Habermas. Abingdon, Oxon: Routldge.

Heelan, Patrick A. (1998) "Scope of Hermeneutics in the Philosophy of Natural Science." Studies in the History and Philosophy of Science 29: 273-298.

Heelan, Patrick A. (2016) The Observable: Heisenberg's Philosophy of Quantum Mechanics, ed. Babette Babich. Oxford: Peter Lang.

Heilbron, Johan (2004) "The Rise of Social Science Disciplines in France" [La sociologie durkheimienne: tradition et actualité] Revue européenne des sciences sociales, T. 42, No. 129: 145-157.

Heller, Agnes (1989) "From Hermeneutics in Social Science toward a Hermeneutics of Social Science." Theory and Society 18(3): 291-322.

Hitzler, Ronald, Reichertz, Jo and Schröer, Norbert (eds.) (1999) Hermeneutische Wissenssoziologie. Standpunkte zur Theorie der Interpretation. Constance: Universitätsverlag Konstanz.

Knorr-Cetina, Karin (1999) Epistemic Cultures: How the Sciences Make Knowledge. Cambridge: Harvard University Press.

Kockelmans, Joseph J. (1976) "Hermeneutic Phenomenology and the Science of History." Phënomenologische Forschungen 2: 130-179.

Kockelmans, Joseph J. (1978) "Reflections on Social Theory." Human Studies: A Journal for Philosophy and the Social Sciences 1: 1-15. 
Kockelmans, Joseph J. (1979) “Deskriptive und interpretierende Phanomenologie in Schütz's Konzeption der Sozialwissenschaft.” In: Walter Sprondel and Richard Grathoff (eds.), Alfred Schütz und die Idee des Alltags in den Sozialwissenschaften. Stuttgart: Enke, pp. $26-42$.

Latour, Bruno (1987) Science in Action: How to Follow Scientists and Engineers through Society. Cambridge: Harvard University Press.

Latour, Bruno (1999) Pandora's Hope: Essays on the Reality of Science Studies. Cambridge, MA: Harvard University Press.

Latour, Bruno (2013) An Inquiry into Modes of Existence: An Anthropology of the Moderns, tr. Catherine Porter. Cambridge: Harvard University Press.

Latour, Bruno and Woolgar, Steve (1979) Laboratory Life: The Construction of Scientific Facts. London: Sage.

Lukes, Steven (1972) Emile Durkheim: His Life and Work. New York: Harper and Row.

Lynch, Michael (2016) The Internet of Us: Knowing More and Understanding Less in the Age of Big Data. New York: W.W. Norton

Madison, Gary (1990) "Getting Beyond Objectivism: The Philosophical Hermeneutics of Gadamer and Ricoeur." In: Dan Lavoie (ed.), Economics and Hermeneutics. London: Routledge, pp. 32-57.

McCarthy, George E. (2009) "Understanding Historical Hermeneutics and Practical Science in Weber." In: George E. McCarthy, Dreams in Exile: Rediscovering Science and Ethics in Nineteenth-Century Social Theory. Albany: State University of New York Press.

Mestrovic, Stjepan (2005) Anthony Giddens: The Last Modernist. London: Routledge.

Misgeld, Dieter (1989) "Common Sense and Common Convictions: Sociology as a Science, Phenomenological Sociology and the Hermeneutical Point of View." Human Sciences 6 (1): $109-139$.

Mohr, John W. and Rawlings, Craig (2013) "Four Ways to Measure Culture: Social Science, Hermeneutics, and the Cultural Turn." In: Jeffrey C. Alexander, Ronald Jacobs and Philip Smith (eds.), The Oxford Handbook of Cultural Sociology. Oxford: Oxford University Press, pp. 70-113.

Moses, Jonathon and Knutsen, Torbjørn (2012) Ways of Knowing: Competing Methodologies in Social and Political Research. London: Palgrave Macmillan.

Okrent, Mark (1984) "Hermeneutics, Transcendental Philosophy and Social Science." Inquiry 27: $23-49$.

Pierozak, Isabelle (2016) "Pourquoi une sociolinguistique (de la /) en réception? Citation et conception de la recherche / professionalité du chercheur." Glottopol 28: 206-225. Online: http://www.univ-rouen.fr/dyalang/glottopol.o

Pietsch, Wolfgang, Jörg Wernecke, Max Ott, eds. (2017) Berechenbarkeit der Welt?: Philosophie und Wissenschaft im Zeitalter von Big Data. Frankfurt: Springer.

Rorty, Richard (2003) "Analytic and Conversational Philosophy." In: Carlos Prado (ed.), A House Divided: Comparing Analytic and Continental Philosophy. Amherst, NY: Humanity Books, pp. $17-32$.

Rose, Hilary (1994) Love, Power and Knowledge: Towards a Feminist Transformation of the Sciences. Bloomington: Indiana University Press.

Scheler, Max (1980) Problems of a Sociology of Knowledge, tr. Manfred Frings. London: Routledge. 
Schmaus, Warren (1994) Durkheim's Philosophy of Science and the Sociology of Knowledge: Creating an Intellectual Niche. Chicago: University of Chicago Press.

Schütz, Alfred (1967) The Phenomenology of the Social World. Evanston: Northwestern.

Sedgwick, Peter R. (2007) Nietzsche's Economy: Modernity, Normativity and Futurity. London: Palgrave McMillan.

Sherrat, Yvonne (2006) Continental Philosophy of Social Science: Hermeneutics, Genealogy, and Critical Theory from Ancient Greece to the Twenty-First Century. Cambridge: Cambridge University Press.

Simon, Joseph (1989) Philosophie des Zeichens. Berlin/New York: De Gruyter.

Staudigl, Michael and Berguno, George (eds.) (2014) Schutzian Phenomenology and Hermeneutic Traditions. Frankfurt a.M.: Springer.

Stingl, Alexander (2015) The Digital Coloniality of Power: Epistemic Disobedience in the Social Sciences and the Legitimacy of the Digital Age. Lanham: Lexington.

Thouard, Denis (2005) "Wie Flacius zum ersten Hermeneutiker der Moderne wurde. Dilthey, Twesten und Schleiermacher und die Historiographie der Hermeneutik.” In: Jörg Schönert and Friedrich Vollhardt (eds.), Die Geschichte der Hermeneutik und die Methodik der textinterpretierenden Disziplinen. Berlin/New York: De Gruyter, pp. 265-280.

Trigg, Roger (1985) Understanding Social Science. Oxford: Basil Blackwell.

Warnke, Georgia (1985) "Hermeneneutics and the Social Sciences: A Gadamerian Critique of Rorty." Inquiry: An Interdisciplinary Journal of Philosophy 28(1-4): 339-357.

Weber, Max (1949) The Methodology of the Social Sciences. New York: Free Press.

Weber, Max (1988 [1922]) Gesammelte Aufsätze zur Wissenschaftslehre, ed. Johannes Winckelmann. Tübingen: Mohr/Siebeck.

Ziman, John (1976) The Force of Knowledge: The Scientific Dimension of Society. Cambridge: Cambridge University Press. 


\section{Table of Contents}

List of Abbreviations - IX

Babette Babich

Hermeneutic Philosophies of Social Science: Introduction - 1

I Science and Method: Towards Hermeneutic Phenomenology of Social Science

Joseph J. Kockelmans

Toward an Interpretative or Hermeneutic Social Science - 25

Patrick Aidan Heelan

Quantum Mechanics and the Social Sciences — 51

Hans-Herbert Kögler

A Critical Hermeneutics of Agency: Cultural Studies as Critical Social Theory -63

Eric S. Nelson

Overcoming Naturalism from Within: Dilthey, Nature, and the Human Sciences -89

Steve Fuller

Hermeneutics from the Inside-Out and the Outside-In-And How

Postmodernism Blew It All Wide Open — 109

II

\section{Reflexive and Relational Hermeneutics}

Steven Shapin

The Sciences of Subjectivity - 123

Dimitri Ginev

Studies of Empirical Ontology and Ontological Difference - 143 
VI $ـ$ Table of Contents

Babette Babich

Hermeneutics and Its Discontents in Philosophy of Science: On Bruno Latour, the "Science Wars", Mockery, and Immortal Models - 163

Gary Madison

On the Importance of Getting Things Straight -189

Saulius Geniusas

Hans-Georg Gadamer's Concept of the Horizon and Its Ethico-Political

Critique - 199

III Practice and Application: Hermeneutics, Social Theory

Duška Franeta

Gadamer's Hermeneutics as Practical Philosophy — 219

Bernt Schnettler, Hubert Knoblauch \& Jürgen Raab

The 'New' Sociology of Knowledge - 237

Didier de Robillard

Taking Plurality Seriously with Michel De Certeau: From History to 'Reception Sociolinguistics' -267

Barry Allen

Pragmatism and Hermeneutics -287

Paul Fairfield

Make It Scientific: Theories of Education from Dewey to Gadamer - 295

IV Truth and Life: Life-Philosophy and History, Psychology and Theology

Simon Glynn

The Hermeneutical Human and Social Sciences - 315 
Harald Seubert

Life, Metaphysics, History: Reflections on the Contemporary Relevance of Dilthey's Philosophy of Life - 341

Leonard Lawlor

Four Fundamental Aspects of the Reversal of Platonism — 357

Robert C. Scharff

Heidegger: Hermeneutics as "Preparation" for Thinking — 373

David B. Allison

Hermeneutic Reflections on Descartes' Introduction to His Meditations on First Philosophy - 387

List of Contributors -427

Index -431 